\title{
French AIDS research plan launched
}

\section{Paris}

THE appointment of Professor Jean-Paul Levy to coordinate AIDS (acquired immune deficiency syndrome) research augurs well for the success of the French national research programme, announced in May (see Nature 328, 3; 1987). Levy (53) is professor of haematology at the University of Paris V, is director of an immunology and oncology laboratory at the Hoprital Cochin in Paris and has worked on cellular immunology and retroviruses since the 1960 s.

Part of the strength of Levy's new position is that he will be responsible for coordinating work supported by the two principal research councils, CNRS (Centre National de la Recherche Scientifique) and INSERM (Institut National de la Santé), which at present support nearly all AIDS research (including some at the Institut Pasteur). The two research councils will spend about 60 per cent of the FF100 million ( $£ 10$ million) budget allocated by the science ministry to the new research programme, with the remainder channelled through the Institut Pasteur, industrial companies such as Transgène and other smaller groups.

Levy, who has been a member of the INSERM directorate since 1980 , says that while the link between CNRS and INSERM is an essential feature of the new research programme, it will nevertheless be subordinate to the Programme National de Recherche sur le SIDA, known as PNRS, whose direction will be determined by the government-appointed committee which includes science minister Jacques Valade (chairman), biochemist Pierre Louisot (vice-chairman) and Alain Pompidou from the Ministry of Health.

Levy believes that he and the PNRS committee have a strategic function. Although at first concerned with the selection and coordination of research projects and the allocation of funds, their objective is "to develop AIDS research and, more generally, research in human retroviruses in France to the greatest possible extent". Although 40 INSERM and 25-30 CNRS laboratories are already involved in AIDS research, Levy suspects that this may not be sufficient "if we are to compete internationally", for which reason he believes part of his task will be to help reorientate certain research groups towards "major problem areas". This may entail the creation of new laboratories, as with the intended move, later this year, of JeanClaude Chermann from the Institut Pasteur to set up a virology laboratory at the Luminy University (near Marseilles).

In contrast with the programme of the British Medical Research Council
(MRC), whose more limited budget has suggested a concentration on drugs and vaccines (see Nature 327, 355; 1987), the French programme will be broadly based. It is now proposed that representatives of laboratories working on 12 major research themes should take part in discussions to decide what work deserves support and, ultimately, which laboratories should do the work. Levy and the PNRS committee will then allocate budgets and other resources and encourage links with industry for the in vitro testing of antiviral molecules and other screening tasks.

The final distribution of the funds for 1987-88 will not be decided until all the project groups have met, but priority will be given to the search for a vaccine, trials of antiviral and other therapeutic agents and epidemiology. It is also intended to create new virology and screening laboratories throughout France, recruiting the people needed from abroad if necessary.

Research programmes whose organization has already been decided include an attack on the nucleoside inhibition of reverse transcriptase, the inhibition of the TAT protein of the human immunodeficiency virus (HIV), nonsense RNA,

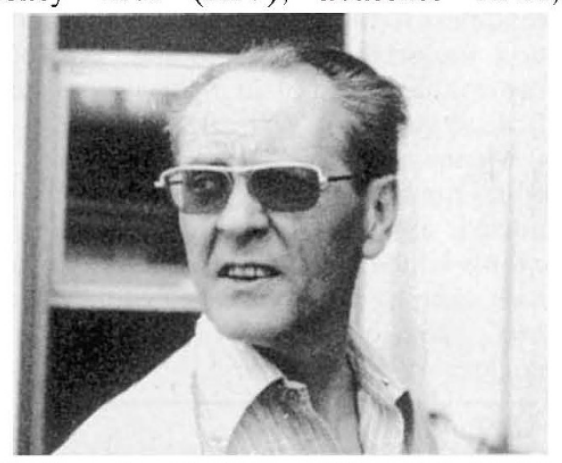

Professor Jean-Paul Levy - "Monsieur AIDS". studies of the viral coating and the transmission of virus from mother to fetus.

According to Louisot, the new AIDS budget, which is an addition to existing research funds, is a "significant" investment by the French government and should benefit "virology and molecular biology as a whole". Saying that "for once we have an initiative that is intelligent, well conceived and constructive", Louisot also says that the budget will have to be maintained for several years if it is to be effective and that, even then, the new budget will be dwarfed by the funds available in the United States. That is why, Louisot says, France will be looking, in August this year, for an enlargement of the research programme on a European scale. He believes that a joint study by INSERM/CNRS and MRC could be a starting-point for such a project.

Peter Coles
Spain's plans for science Barcelona

The CSIC (Consejo Superior de Investi aciones Científicas), the Spanish research council, has outlined a programme that, for the first time, defines the activities of its 1,700 researchers and 94 institutes during the next five years. The programme has been presented to the Interministerial Commission of Science and Technology for possible inclusion in the National Plan for Research, now being drafted. The programme (CSP) is a 536-page document containing a description of its purpose and methodology, how research groups should apply for funds and a proposed budget for CSIC. The main part of the document is devoted to the CSIC's scientific objectives which are grouped in $\mathbf{2 2}$ subprogrammes.

One of the subprogrammes is called "General Promotion of Knowledge" and will cover basic research not included elsewhere, including relations of Spain with the United States and with the Arab world.

The budget of CSIC will rise steadily during the five-year period to 30,000 million pesetas ( $£ 150$ million) in 1992 , a figure considered conservative in the light of increased expenses in many research fields. It allows for 6.5 per cent annual increase in CSIC's scientific staff to 2,500 researchers in 1992, and around 2,000 fellowships for graduate students and postdoctorals. P.P.

\section{Indian/Soviet agreement}

\section{New Delhi}

INDIA and the Soviet Union have become partners in frontier areas of research under a pact on science cooperation signed in Moscow last week by the Indian prime minister, Rajiv Gandhi, and the Soviet leader, Mikhail Gorbachev. The agreement, which covers the period up to the year 2000, was set in train during Gorbachev's visit to New Delhi last November, and a working party outlining the agreement now reached was set up in Moscow in March (see Nature 326, 632; 1987). K.S.J.

\section{Bulgaria and the sea}

\section{London}

Bulgaria, which at the beginning of the year declared its right to a 200-mile offshore "economic zone" along the Black Sea coast, has announced the establishment of a "technological centre for marine resources". Charged with the task of "undertaking national work on studying and utilizing the riches of the sea", the centre is an interdisciplinary association of (so far) 14 governmental, economic and academic bodies. According to the daily Otechestven Front, the centre has already started work on six "urgent" projects, including designing a towable submersible with an operational depth of $3,000 \mathrm{~m}$ and technology to allow divers to work outside a craft at a depth of $200 \mathrm{~m}$. 